\title{
A Suggested Strategic Roadmap for Public Egyptian Universities to Adopt and Adapt to the Requirements of the Fourth Industrial Revolution and Society 5.0 to Prepare Students for the Future Labor Market
}

\author{
Hanaa Ouda Khadri Ahmed \\ Associate Professor, Faculty of Education - Ain Shams University, Cairo- Egypt
}

\begin{abstract}
Currently, the world is facing an unprecedented challenge which is "youth bulge" with a high rate of unemployment. It is argued that the employability challenges will be compounded by the impacts of the Fourth Industrial Revolution (4IR) and Society 5.0, and "Open talent economy" is the new economy replacing traditional permanent employees with talented "free lancers" to perform the required work from anywhere in the world. Currently, institutions around the world prefer to employ those who have skills for specific projects. Gig economy primarily depends on two forms of work: "crowd work" and "work on-demand". In addition, in the last five years, "artificial intelligence" (AI) has begun to replace people in many of routine jobs, and will continue to replace people in new unimaginable jobs that may arise in the future due to the continuous developments of smart technologies. Accordingly, universities all over the world will face a new problem of preparing students for a new way of life and work with a somewhat uncertain future in the coming era that involves a new industrial revolution whose repercussions are unprecedented.Accordingly, there is increasing trend that calls for the necessity of preparing a flexible or liquid workforce able to constantly adapt itself to the requirements of fast-changing labor market, and establishing a culture of flexibility in moving between businesses according to the needs of the labor market which witnessed the emergence of new types of labor across the world. If universities failed to align employability competences with the requirements of 4IR and Society 5.0, the unemployment gap will increase. Thus, the main objective of this study is to propose a strategic roadmap for public Egyptian universities to adopt and adapt to the requirements of the fourth industrial revolution and society 5.0 to prepare students for the future labor market. To achieve this objective, the author adopted both descriptive and exploratory research design, and used mixed methods research approach. Since the requirements of 4IR and Society 5.0 and Gig economy do not depend on national educational institutions that operate in accordance with national standards, but reliance is on the standards set by transnational "digital institutions" and platform companies, so the national contexts will have minor influence on practices and structure of university education systems, therefore the suggested strategic proposal may be applied by many universities in different educational contexts.
\end{abstract}

Keywords: The Fourth Industrial Revolution; Society 5.0; Strategic Roadmap; Education 4.0; Work 4.0; Egyptian Universities; Gig economy.

DOI: $10.7176 / \mathrm{JEP} / 11-29-03$

Publication date:October $31^{\text {st }} 2020$

\subsection{Introduction}

\subsection{Background of the Study}

There is a symbiotic relationship between university and society. This relationship is marked by ongoing mutual exchange and influence. At the beginning of the third millennium, a new and totally different world from what we had previously witnessed was formed as a result of the ramifications of the Fourth Industrial Revolution (Ir4) which is also called industry 4.0. The main distinctive feature of (Ir4) is the integration of the physical entities with their "virtual twins" in smart factories through employing cutting edge industrial smart technologies (Hermann, et al., 2015). The requirements of the Fourth Industrial Revolution (Ir4) representing great challenges to the learning paths that most of universities offer today and The future economy will search for workforce with specific competences and skill sets that enable them to cope with the requirements of current and future digital transformation and smart work environments supported by artificial intelligence and robotics (WEF,2017).Therefore, adaptability is one of the main challenges that universities will face to cope with current and future digital transformation, since it is expected that the Fifth Industrial Revolution will not take long. Accordingly, new priorities that higher education institutions must address have emerged, these priorities are: Industrial cognitive science" and "automation electronics" and curricula based on the interaction between robots and human systems, as well as processing big data (Wisskirchen et al., 2017). Therefore, governments should develop evolving and dynamic educational system that can prepare students for creative work, non-linear career paths that will be required in the new phase of digital globalization (globalization 4.0) (Schwab 2018; Baldwin 2019) which its implications will fundamentally change the nature and structures of existing institutions and jobs, as procedural and rule-based work are being automated and robotized. Thus, individuals have to constantly update 
their personal and digital skills to keep coping with technological developments that will control the future development paths of societies, institutions, and the nature of jobs (Wadhwa, 2016).

To keep pace with the current global digital transformations, universities must change their paradigms and structures to offer more personalized precision education based on innovation, creativity, cooperation, knowledge production and exchange, and complex problem solving (Tsekeris, 2019; Brailas et al., 2017). In addition, students should gain at universities new digital skills which represent a mixture of hard and personal skills including sympathy, emotional intelligence, communication, speaking to the public, dealing with work pressure and stress, and the ability to create and coordinate human networks (online or offline), managing participatory information platforms, the emerging Internet of Things and the spatial web (Web 3.0) (Tsekeris, 2019; Brailas et al., 2017; Park, 2016).

As for the relationship between national contexts and employment in the new economy, transnational nationality is a very important advantage of the new economy, as individuals from anywhere in the world can work online (Martin et al., 2016). Given the differences in national education systems due to the impacts of national contexts on learning practices, it can be argued that crowd work does not depend on national educational institutions that operate in accordance with national standards, but the governing factor is the standards developed by transnational "digital institutions" and platform companies hence, national contexts will have minor influences on practices and structure of educational systems (Lehdonvirta et al., 2018).

It is obvious that the new economy on one hand, creates new jobs and on the other hand, destroys others. Accordingly, there are many questions should be taken into consideration: How will work environments be organized in the future? What are the alternatives to employment? How can public Egyptian universities cope with the new transformations in economy and be prepared for more unprecedented transformations?

\subsection{Problem statement}

Intelligent automation and robotics have become the new workforce. Therefore, university education will face great challenges in preparing students for a new way of life and work with a future involving a new industrial revolution whose repercussions are unprecedented. Hence, public Egyptian universities should adopt and adapt to the requirements of the Fourth Industrial Revolution and Society 5.0 to prepare students for the future labor market. The question that arises here is: What is the suggested strategic roadmap for public Egyptian universities to adopt and adapt to the requirements of the fourth industrial revolution and society 5.0 to prepare students for the future labor market?

To make this main question more precise, four sub-questions were added:

2.1. What is the conceptual and theoretical underpinnings of the Fourth Industrial Revolution (IR4) and Society 5.0 ?

2.2. What are the implications of the Fourth Industrial Revolution on demographics of present and future workforce?

2.3. What are the implications of the Fourth Industrial Revolution on public Egyptian universities?

2.4. What are the procedures that Egypt have taken to be ready for Industry 4.0 and society 5.0?

2.5. How can public Egyptian universities adopt and adapt to the requirements of the Fourth Industrial Revolution and Society 5.0 to prepare students for the future labor market?

\subsection{Significance of the study}

3.1. The study main objective is to develop a strategic roadmap for public Egyptian universities to adopt and adapt to the requirements of the fourth industrial revolution and society 5.0 to prepare students for the future labor market. The suggested strategic roadmap elements were grounded soundly in theoretical and conceptual frameworks of related literature and presented in a simplified and practical manner so that policymakers, university academic faculty and staff understand its components and how strategic objectives could be achieved with the aim of enhancing universities abilities to prepare students for the future labor market according to the requirements of the fourth industrial revolution and society 5.0.

3.2. While it is not the intention of the study to generalize the strategic roadmap to other universities, the strategic roadmap might provide insights to other international universities since the requirements of 4IR and Society 5.0 and Gig economy do not depend on national educational institutions that operate in accordance with national standards, but reliance is on the standards set by transnational "digital institutions" and platform companies, so the national contexts will have minor influence on practices and structure of university education systems, therefore the suggested strategic proposal may be applied by many universities in different educational contexts.

\subsection{Scope and Objectives of the Study}

The main objective of this study is to propose a strategic roadmap for public Egyptian universities to adopt and adapt to the requirements of the Fourth Industrial Revolution and Society 5.0 to prepare students for the future labor market. The study focused on the following objectives: 
4.1 Defining the requirements of the Fourth Industrial Revolution and Society 5.0 that public Egyptian universities should respond to.

4.2 Critically analyze the fundamental underpinnings of the Fourth Industrial Revolution (IR4) and Society 5.0. 4.3 Identify challenges that face public Egyptian universities in terms of adopting and adapting of the requirements of the Fourth Industrial Revolution and Society 5.0.

4.4 Identify the current status quo of Egypt's readiness for Industry 4.0 and society 5.0.

4.5 Propose a strategic roadmap for public Egyptian universities to adopt and adapt to the requirements of the Fourth Industrial Revolution and Society 5.0 to prepare students for the future labor market.

\subsection{Research methodology}

This study adopted both descriptive and exploratory research design, and used mixed methods research approach. A semi-structured interview and a questionnaire were used to achieve the study objectives. The questionnaire consisted of closed and open questions. The questionnaire included three main parts: The first part prepared to collect basic data, the second part investigated the experts' responses to the current status quo of Egypt's readiness for the Fourth Industrial Revolution and Society 5.0 (SWOT analysis) and the third part was about assessing the proposed strategic roadmap. Experts' responses were ranked by Likert rating scale. In order to analyze the questionnaire data, SPSS software version (23) is used.

\subsection{Population and sampling}

The sample of the study consisted of 63 academic experts from different colleges (Education, Science, Arts, Engineering, and Medicine) at six public Egyptian universities (Ain Shams University, Cairo University, Helwan University, Mansoura University, Assiut University, and Tanta University). Purpose sampling was used to get opinions from academic experts, most of them (47), who operate on the cutting edge of technology and technological adoption, since managing the challenges of the Fourth Industrial Revolution (IR4) and Society 5.0. requires thriving universities deeply engaged with the developments and use of emerging smart technologies.

Experts are asked to judge the questionnaire data in terms of the following:

a) Are the identified SWOT factors reflect the current status quo of Egypt's readiness for the Fourth Industrial Revolution and Society 5.0?

b)Identify additional SWOT factors that are not covered in the questionnaire.

c) Demonstrate agreement or disagreement with the components of the proposed strategic roadmap.

d)Identify additional information that are not covered in the questionnaire.

After the academic experts evaluated SWOT analysis and the suggested strategic roadmap, their recommendations were incorporated in the final SWOT analysis and the suggested strategic roadmap.

\subsection{Literature review}

\subsection{The Fourth Industrial Revolution (IR4) and Society 5.0: Conceptual and theoretical frameworks}

Before addressing the fourth industrial revolution and society 5.0, the most important features of the previous three industrial revolutions will be briefly outlined. The concept of a revolution in the educational context refers to a massive and rapid series of changes that lead to fundamental transformations in society. These changes may be social, political, economic, industrial, technology, or of any other kind. The first industrial revolution, that was based on steam king, began in the textile British factories at the end of the eighteenth century, and from them they spread all over the world, and the gradual replacement of labor with machinery began, and at the same time a parallel development occurred in the means of transportation that led to expansion in the establishment of major industries and companies in Britain and later the global expansion in the industrial sector increased, and new scientific methods were used in managing industries and companies(Voskoglou,2016). Various names and definitions have been proposed for many industrial revolutions that have occurred since then. According to the World Economic Forum (WEF), the first industrial revolution was marked by its use of steam and hydropower, followed by the second industrial revolution, which began in the mid-nineteenth century, which employed the power of electricity and mass production in large quantities of products that subjected to uniform standards on production and assembly lines. However, many social thinkers believe that the second industrial revolution that ended by the middle of the twentieth century, is in itself considered as an integral part of the first industrial revolution (Rifkin,2011). The Third Industrial Revolution - or, according to the alternative view (the Second Industrial Revolution) - is also known as the "Era of Automation" which started in the 1940s, and was characterized by the development of electronics, automated production, and the gradual replacement of human beings with computers as a means of controlling production quality. (Block,2018).

\subsubsection{The Fourth Industrial Revolution (IR4): Origins and developments}

The previous revolutions have paved the way to the emergence of digital age. The idea of a new industrial revolution has been addressed by many researchers since the beginning of the twenty-first century (Rifkin, 2011,2014; Anton, Silberglith and Schveeder, 2015). The famous social thinker Jeremy Rifkin was the first one 
who referred to the beginning of the Fourth Industrial Revolution (which was called from his own perspective the third industrial revolution) in his two books that have been published in 2011 and 2014. Rifkin described how integration and complementarity between internet technology, new emerging technologies, renewable energy, and 3D printing have enabled this unprecedented revolution to happen. These new emerging technologies are equipped with sensors to transfer energy from one place to another through the Internet, and through 3D printers that can visualize 3D models of any material (powder, plastic, wax, silk, metals, ... etc.) across the web, multiple copies can be reproduced at very a marginal cost. (Rifkin, 2011,2014). In 2015, when Klaus Schwab, the founder and president of the World Economic Forum, introduced in his article published in " Foreign Affairs " magazine the term "the Fourth Industrial Revolution"(4IR) for the first time, it was almost identical to the meaning put forward by Rifkin, Schwab states that, world is already at the beginning of the Fourth Industrial Revolution, that has started with the emergence of Cyber-Physical Systems (CPS) that are controlled by computer programs via the internet, and these systems have a huge capacity for continuous improvement in a striking way. The Fourth Industrial Revolution was the subject of the annual meeting of the World Economic Forum in 2016 in Davos, entitled "Mastering the 4IR", due to the extensive global ascension in automation and artificial intelligence and the emergence of the gig and sharing economy. (Schwab, 2016). Germany has supported the concept of the fourth industrial revolution and used the term "Industry 4.0" in its industry plan entitled" Germany's Industry 4.0 strategy: Rhine capitalism in the age of digitalization, "Germany now considers Industry 4.0 its key target of strategic economic and industrial policy (Schroeder, 2016). Experts predict that the fourth Industrial Revolution (IR4) maturity stage will be in 2025-2030.

\subsubsection{Industry 4.0: Concept definitions}

Industry 4.0 has emerged as a new industrial era characterized by digitalization, unprecedented development of information and communication technology, and automation. The term "Industry 4.0" was first introduced in 2011 at the Hanover Fair, then a group representing German businessmen, politicians, and scientists defined Industry 4.0 as the industry that aims to achieve competitiveness of industry by promoting the integration of "CyberPhysical Systems" (CPS) in production processes. Hermann, Pentek and Otto in 2015 defined industry 4.0 as an umbrella term used to describe a set of related technological developments that contributed to the digitization of business environments. This definition is consistent with McKinsey's definition that described Industry 4.0 as the next stage of the digitization of the industrial sector, which was achieved through the following four innovations:

A- Amazing increase in data sizes.

B- Advanced computing capabilities.

C- Communication through large-scale networks with low energy consumption.

D- The emergence of $t$ capabilities of business intelligence, new forms of human-machine interaction such as Touch Interfaces and augmented reality systems, and improvements in methods for transferring digital world content to physical world, such as advanced robots and 3D printing.

\subsubsection{Society 5.0 -"Super Smart Society": concept and distinctive features}

Society 5.0 is the future of modern society. The first to coin Society 5.0 term is the Japanese government, meaning a community that is a human-centered society that relies heavily on very smart advanced technology in an unprecedented way beyond the previous stages of human history, and focuses on many "smart" applications that will make the society becomes an intelligent, fully interconnected and sustainable system. Society 5.0 has a distortive set of characteristics: (1) full use of information technology communications (2) focus on society (3) participation of all members of society (4) shared values: sustainability, inclusiveness and effectiveness, and smart power (5) the development of economic turmoil (Salgues, 2018). Digital infrastructures and platforms form the basis of society 5.0. The architecture of the infrastructures is based on smart technologies such as artificial intelligence, robots, the Internet of Things, closed chains, augmented and virtual reality, and process automation (RPA) robotic. These technologies have now reached a very high level of maturity that provide society with high levels of social and economic empowerment. In Japan, the government initiated a strategy targeted Society 5.0 and used emerging smart technologies to build a "cyber-physical society" consisting of integration and interaction between what is cyber and human or even material. Although, Society 5.0 is more human-centered and beyond what actually happened in the age of knowledge (Harayama 2017, pp. 8, 10; Medina-Borja ,2017, p. 235). Yet, there is a clear paradox in building an increasingly human-centered society with the rapid and progressive expansion of social robots, ... and other intelligent technologies that are no longer considered to be negative tools to implement human instructions, but they are able to learn and think (Government of Japan, 2016a, p. 13). In the future, there will be more and more complementarity and homogeneity between the real and the artificial reality to build highly collaborative environments in multiple time and space dimensions to create collaborative knowledge systems and technology-human partnerships .(Medina-Borja, 2017, p. 235) The community of 5.0 includes two new types of members that have not been existed in any previous human society, they are autonomous robots and artificial intelligence that will not be just negative entities that only implement people orders, or just will be merely components of their environment, and certainly will not reach the human stage either in terms of recognizing rights like human rights, or as citizens "politically speaking” (Wallach and Allen 2008; Gunkel 2012; 
Sandberg 2014). Soon, autonomous robots and artificial intelligence will be participants in Society 5.0 in the same way that pets are an integral part of human society in various civilizations and over the ages( Cohen 2002; Haraway 2003; Charles and Davies 2011). In this context there is a question that arises:

1. How can public Egyptian universities prepare the current and future workforce for the Fourth Industrial

Revolution and Society 5.0 ?

Society 5.0 is based on "integrating physical (real world) and cyberspace and trying to best maximizing the potentials of information and communications technology (Yasuura ,2017, p. 221). Government institutions, universities, and companies are currently cooperating to implement the 5.0 Society model by employing advanced technologies that industry 4.0 best uses to become Society 5.0 the first "Super Smart Society" (Harayama 2017; Ferreira and Serpa 2018). One of the distinctive features of Society 5.0 is the availability of huge amounts of personal data collected and shared across system networks which offer opportunities to design new innovative solutions and services for individuals participating in these systems. Society 5.0 has a set of ambitious goals, which are summarized as follows (Bryndin, 2018, p. 12; Medina-Borja 2017, p. 235):

1. Building infrastructures integrating the digital and real spaces of society 5.0, which will be able to accurately respond to a wide range of social needs, and build a society that will enable people to easily obtain high-quality services and products, and overcome the differences that result from variations in age, gender, geographic region, and language.

2. Offering equal opportunities for all individuals and providing highly collaborative environments that support the capabilities of everyone to develop these capabilities to the highest possible levels.

3. Best utilizing emerging technologies to remove physical, administrative and social barriers so that an individual can achieve self-actualization.

4. Everyone, including the elderly, and women can live safe, healthy, and comfortable life, and can choose the lifestyle that suits him/her.

6. Harnessing the interaction between technology and people to build a sustainable human-centered life.

\subsection{Implications of the fourth industrial revolution on demographics of present and future work-force 6.2.1 Transformation of the labor market}

Intelligent automation and robotics have become the new workforce. This is evidenced by the increase in the number of industrial robots operating around the world to about 1.6 million robots in 2015 , and increased by an additional one million robots in 2019. A report issued by McKinsey Global Institute in July 2016 indicates that the most vulnerable professions for automation and robotics use are in industry sector (59\%), food services $(73 \%)$, retail trade $(53 \%)$ and hotel sector $(73 \%)$ since, these sectors are experiencing significant technological development. Over the next twenty years, about (35\%) of jobs will disappear due to the use of new smart technologies (Deloitte, 2014). In the last five years, many applications of "artificial intelligence" began to replace humans in an increasing number of routine jobs, and scientists also expected that these applications will perform many new functions in the future due to the continuous development of smart technologies (Mustafa Kamal et al.,2019). The World Development Report 2019, issued by the World Bank, entitled (The Changing Nature of Work), indicated that the phenomenon of rapid increase in the numbers of robots operating throughout has two aspects: fears of losing jobs, and emerging technology provide opportunities for new jobs to appear, increasing productivity, and developing service delivery.

Researchers expected that Industry 4.0 requires challenging skills (in programming, data analytics, etc.) to manage automated and robotic systems in addition to interpersonal skills (Lorenz, et al., 2015). A collaborative report conducted by Deloitte and the Global Business Coalition for Education identified four skill categories provide the skills needed for industry 4.0. (Deloitte, 2018) as shown in figure 1. 


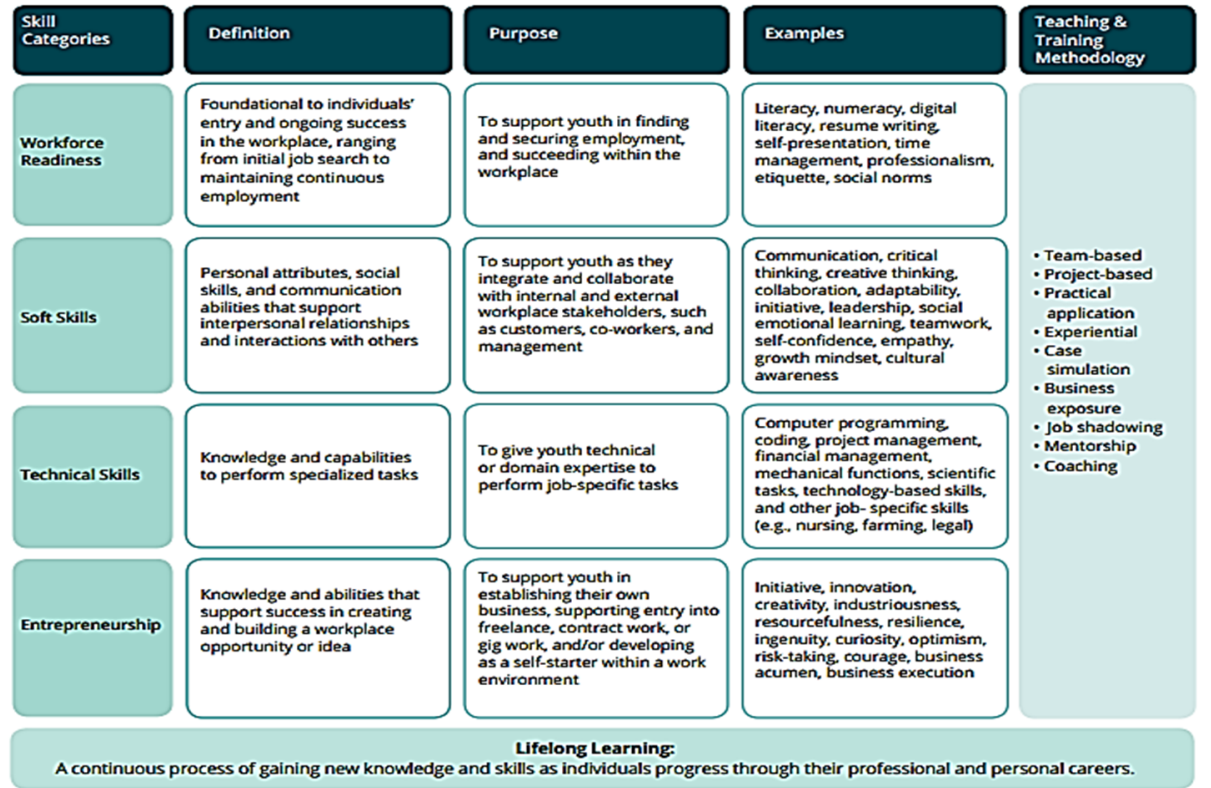

Figure 1: Skills needed for 4IR.

Source: (Deloitte, 2018).

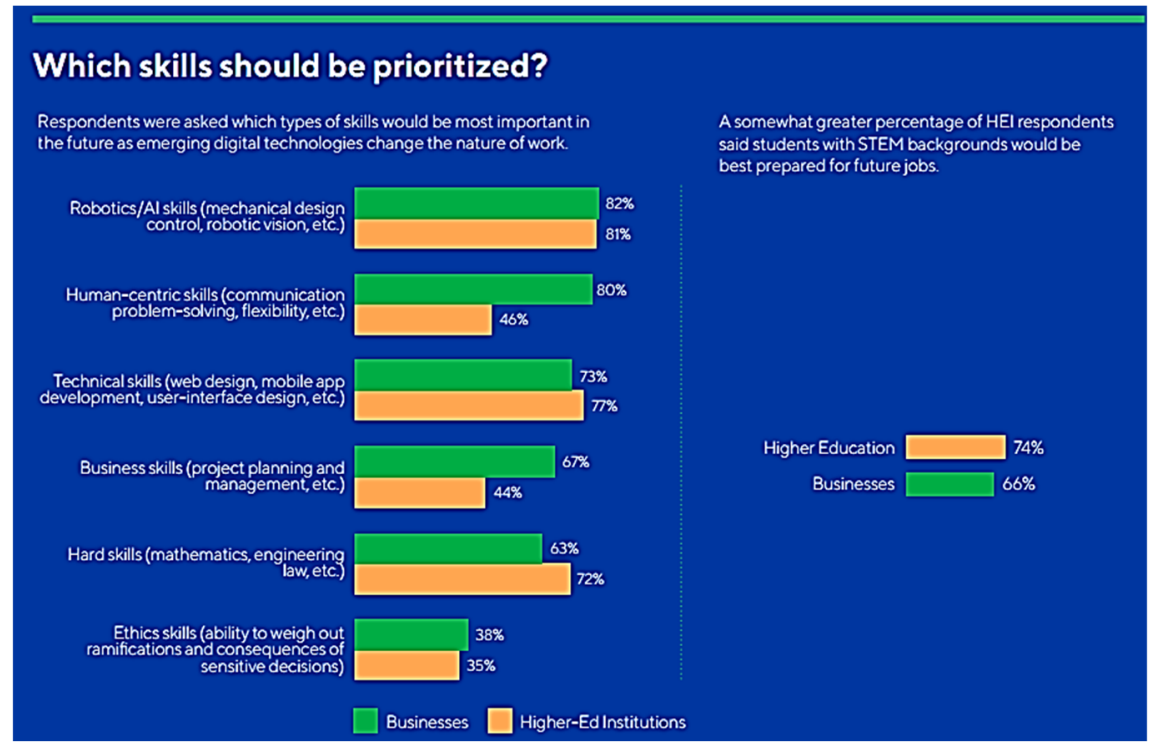

Figure 2: The most important skills in the future .

Source: (Bahl, Cook, and Nerurkar, 2018).

Cognizant's Center for the Future of Work published in 2018 a whitepaper, entitled" Relearning how we Learn from the Campus to the Workplace". The researchers investigated the most relevant future skill areas through surveyed global 601 top business executives at outstanding institutions and 262 higher education institutions. The paper defined skills required in the future as shown in figure 2. In the same context, the researchers defined the top priorities for preparing the current/future workforce in the next five years as shown in figure 3 (Bahl, Cook, and Nerurkar, 2018). I believe that these skills should be the foundations of developing intended learning outcomes and standards of university education. 


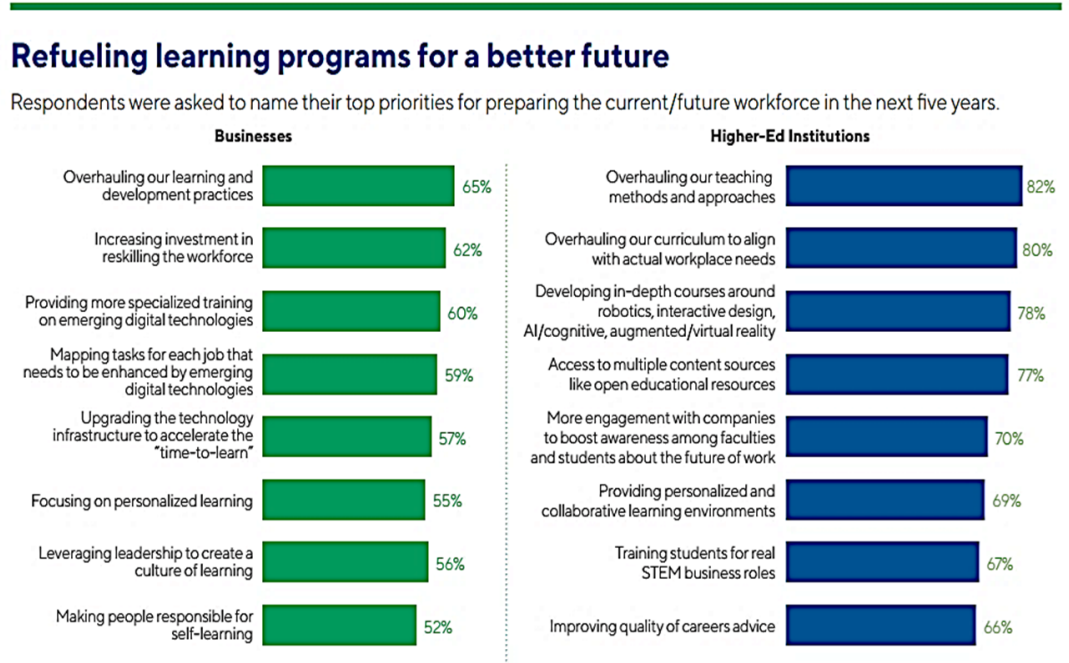

Figure 3: The top priorities for preparing the current/future workforce . Source: (Bahl, Cook, and Nerurkar, 2018).

Thus, university education will face great challenges in preparing students for a new way of life with a future involving a new industrial revolution whose repercussions are unprecedented. Hence, educational decision-makers should develop strategies to face the increasing inconsistencies between the required and the offered skills, which can lead to impeding economic growth and threatening social stability. Many recent studies have argued that the current university students will not be ready to work after completing their education in light of the new changes. Therefore, a change must be made in university education systems to be able to prepare the students for the future labor market. Some argue that emerging science, technology, engineering, mathematics and programming skills will be the most important skills for the future.

\subsubsection{Gig economy}

During the first decade of the third millennium, the world economy entered a new phase marked by the emergence of completely new forms of online business. "Open talent economy" is the new economy replacing traditional permanent employees with talented "free lancers" to perform the required work from anywhere in the world. Currently, institutions around the world prefer to employ those who have skills for specific projects. Gig economy primarily depends on two forms of work: "crowd work" and "work on-demand" (De Stefano, 2016; Schwartz, et al. ,2016). Economists are currently interested in the economy of self-employment, "Gig economy", and the name "Gig" was taken from musicians who partly in the Jazz Clubs in the 1920s. Gig Workers usually work on a variety of part-time jobs. Economists believe that economy of self-employment or economy of participation across digital platforms will expand for a long period of time, because it meets the special needs of various industrial, commercial and service sectors (Hazarika, 2019).

"Gig economy "is still in its infancy in some countries such as: The United States, the United Kingdom, Sweden, Germany and Spain. According to the 2016 report issued by the Organization for Economic Cooperation and Development (OECD), the share of self-employment from the total workforce is the largest in the four developing markets (China, India, Indonesia, and Brazil). The share was the largest in China, where $12 \%$ of the workers earn their income through digital work platforms. The ratio is from 3 to $10 \%$ of workers in mature economies, and more than 30\% in some developing countries. In 14 EU Member States, crowd work" or 'gig work' represents the major source of income for $2 \%$ - $11 \%$ of adults (Pesole et al., 2018).

The European Union information agency for occupational safety and health (EU- OSHA) has examined the profound changes currently taking place in the labor market as a result of the implications of the digital transformation. The study concluded that the transformations in the labor market represent a cumulative product and development of many disparate trends that contributed in building a new reality of the labor market illustrated in figure 4 . The central circle in this figure represents the emerging "new" field of employment online. The external fields represent a group of offline traditional economic activities. The different types of online activity represent points on a continuum between the outer edge of the and initial implications (not connected to the Internet) and the equivalent in the center of economic activities that take place online (EU-OSHA, 2015). 


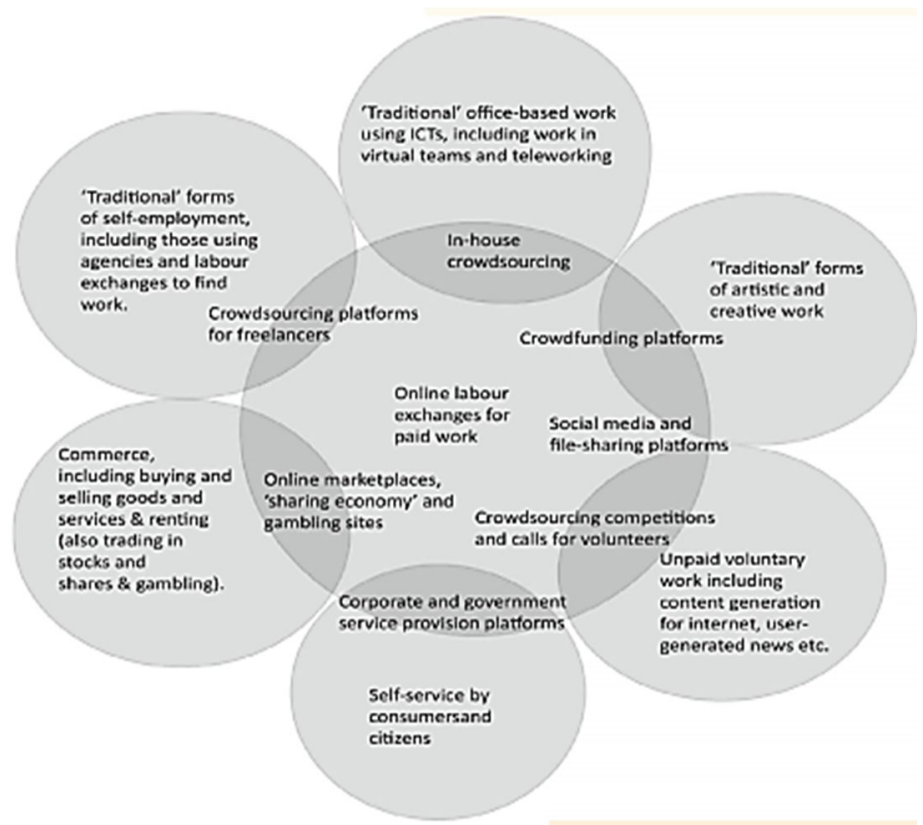

Figure 4: The new labor landscape is an evolution of past offline work practices.

Source: (EU-OSHA,2015).

\subsubsection{Paid Crowd work and Internet-based platforms}

There is increasing trend that calls for necessity of preparing a flexible or liquid workforce able to constantly adapt itself to the requirements of fast-changing labor market, and establishing a culture of flexibility in moving between businesses according to the needs of the labor market which witnessed the emergence of new types of labor across the world termed 'crowd work' which uses Internet-based platforms as mediators between employers and employees (Huws, 2014; Berg et al.,2018). There are two types of crowd work, microwork (CrowdFlower) and freelancing(Upwork), and the difference between them is that the microwork is a large project or a task that has been divided into small tasks so that these tasks are performed by crowd workers from anywhere in the world through teamwork, and these tasks do not take long time, nor requires any specialist knowledge and competencies that go beyond basic computer and internet skills. The identities of the crowd workers are Usually not known, and they are managed through ID numbers (Schmidt, 2017). The second type of crowd work is freelance tasks which are microwork which requires a longer time, compared to the microwork, and specialized professional knowledge and skills. On the one hand, shared work platforms enable crowd workers to publish their personal and professional profiles that include their competencies, qualifications, work experience, assignments and recommendations from past clients. On the other hand, platforms enable business owners to choose crowd workers according to nature of the tasks, the required skills, and professional files (Barnes, Green, \& Hoyos, 2015; Schmidt, 2017). The phenomenon of crowd work is increasing in developing and developed countries. The number of crowd workers in 2015 reached about 48 million, with a total revenue of about $\$ 2$ billion .Crowd work has been increased by $26 \%$ between July 2016 and June, and it is expected that the crowd work phenomenon will expand in 2020, and achieve revenues ranging between $\$ 15$ and $\$ 25$ billion, and it is expected to continue to expand over the next decade, adding to global annual gross domestic product an increase up to $\$ 2.7$ trillion, through the work of 540 million crowd workers worldwide - the equivalent of the European Union population (Kuek et al., 2015). In 2015, the majority of crowd workers were men and less than 35 years old (Manyika et al, 2015). Vili Lehdonvirta conducted a Crowd Learn research project on digitization, artificial intelligence and the future of work, in the period 20172019 in the European Union on how online workers develop their skills to cope with the requirements of work on demand, and the project results provided some aspects about the future of learning and work. The new classification of skills required for online platform work entails: digital skills, a mix of "entrepreneurial", "selfbranding", "communication" and "organizational skills", as well as personal behavior, which are the basic skills necessary for success in online platform markets (Lehdonvirta, Margaryan, and Davies, 2019) 


\begin{tabular}{|c|c|c|c|}
\hline Number of mentions of skill category; deve & $\begin{array}{l}\text { priorto } \\
\text { corring } \\
\text { crowdwork }\end{array}$ & & \\
\hline Skills typology & Examples & & \\
\hline Technical/core skills & - Computer programming, marketing & 228 & 265 \\
\hline Language skills & - English, French, Spanish & 61 & 18 \\
\hline Computer literacy & & 7 & \\
\hline Communication skills & $\begin{array}{l}\text { - Communication skills, handling } \\
\text { customers }\end{array}$ & 51 & 112 \\
\hline Organizational skills & $\begin{array}{l}\text { - Project management, time } \\
\text { management }\end{array}$ & 8 & 56 \\
\hline Personal dispositions/attributes & $\begin{array}{l}\text { - Independence, confidence, creativity. } \\
\text { resilience }\end{array}$ & 18 & 89 \\
\hline Learning to learn & & 1 & 39 \\
\hline Analytical skills & & 1 & \\
\hline Setting up as a freelancer & - Taxes, obtaining business permits & & 28 \\
\hline Obtaining work on platform & - Pricing, applying for work & 17 & 177 \\
\hline
\end{tabular}

Figure 5: Classification of the skills needed to work on demand

Source: (Lehdonvirta, Margaryan, and Davies, 2019)

Figure 5 represents a classification of work skills based on 123 distinct skills acquired by workers before joining the platform's work and 89 skills acquired while working (Lehdonvirta, Margaryan, and Davies, 2019). Work platforms allow the exchange of knowledge between those involved in crowd work and those who use data derived from crowd work markets to develop educational systems (Schmidt, 2017). Crowd workers can conduct self-organizing group learning practices. The online work platforms are not limited to matching the skills of the Crowd workers with the required skills only, but also contribute to developing crowd workers skills and learning processes through skills tests and facilitating access to learning resources (Lehdonvirta, Margaryan and Davies, 2019; Hazarika, 2019).

\subsection{Implications of the fourth industrial revolution on university education}

Industry 4.0 depends on new advanced technologies including nanotechnology, biotechnology, energy storage technology, humanoid, cyber-organism or cyborg, quantum computing, artificial intelligence, robots, Internet of Things, self-driving cars, 3D printing, the Internet of People, ... etc. (Schwab, 2016; Rojko, 2017). These advanced technologies developed new types of systems that will play an important role in the future university education, as these technologies will create a new framework for education 4.0 that aims at building a new workforce with the expertise, skills and competencies needed for industry 4.0 (Mourtzis et al., 2018). The next section summarizes the implications of the Fourth Industrial Revolution on university education.

6.3.1. Intellectual transformations: Post-humanism

"Post-humanism" can be understood as a variety of scientific methods for analyzing phenomena in a way that removes the boundaries between traditional conceptual binaries such as "human versus non-human" and "natural versus artificial" since, society does not include only humans but also non-human entities such as pets and legendary characters. On the academic level, the "post-humanist" movement is a relatively recent topic that dates back to 1977 when Hassan (1977) referred to "post-human culture" in an article published in "The Georgia Review", then the movement evolved rapidly in the 1980s. Trends such as "post-critical humanity" (Herbrechter 2013), "post-cultural humanity", and "post-philosophical humanity" (Miah 2008) have been emerged and many theorists supported these trends such as: Badmington (2006); Ferrando (2013); Graham (2002, 2004); Haraway (, 1991, 2003); Hayles (1999, 2005); Herbrechter (2012, 2013); and Roden (2014).

The "humanization" phenomenon is related to the post-humanist phenomenon, but it differs from it in that it includes processes or dynamics that actually work in a society, and it has a clear impact on removing barriers between man and non-human, and between natural and artificial. The proponents of post-humanism seek to reach a "post-human" position by eliminating disabilities, aging, pain, death, and disease through synergy between nanotechnologies, biotechnology, artificial intelligence and modern cognitive sciences. They also support human cloning practices, virtual reality, human-machine hybridization, and "Mind Uploading" phenomenon that means, according to the post-humanism, human feelings, thoughts, and emotions are limited to the nervous bonding, and human mind is limited to information that can be translated into binary code 0 and 1 that can be downloaded to a computer. The opponents of the post-humanism criticize the ideas that deify technology, and imagine "an exceptional person"(Gladden, 2019).

\subsubsection{Educational transformations}

6.3.2.1 Education paradigm

The paradigm of education has greatly changed over the ages. In ancient times, education was restricted to the elite 
of the society, and it was under the control of the clergy. Teaching and learning methods were very traditional. The learner is a passive recipient and the educator is the absolute leader in the classroom. Technology is not allowed and information is directly transferred from teachers to learners. After the Industrial Revolution, the paradigm governing education has changed, and the focus became on providing individuals with basic knowledge and skills to cope with the requirements of the Industrial Revolution. Education has become a priority for the state, and has become available for all members of society and has grown very quickly. Education 2.0 has been emerged as a response to the emergence of printing and the establishment of universities. Teaching and learning processes have evolved, and universities have targeted promoting academics professional development, conducting advanced research and preparing students to manage their societal affairs. Education 2.0 was characterized by limited access to technology. Education 3.0 was characterized by technology that has transformed the traditional lecture hall into flexible digital environment employing new technologies in the educational processes to effectively deliver information to learners. (Gleason, 2018; Maria, et al., 2016).

\subsubsection{Education 4.0: The era of "digital monarchy"}

Education 4.0 has been emerged as a response to the needs of the Fourth Industrial Revolution, which is characterized by the integration between man and smart technologies to find solutions to problems of societies, and to invent new innovations to promote human well-being. Thus, the learner must be prepared to cooperate and integrate with technologies 4.0 such as hologram, Internet of Things, 3D Printing, biometrics, augmented/virtual reality, artificial intelligence, big data and qr-code and so forth (Halili, 2019). Education 4.0 represents a new paradigm based on Cybergogy which aims to focusing on the learner through building highly collaborative learning environments that make best use of virtual and augmented reality technologies to support learner independence while providing collaborative learning opportunities (Nisha, 2018) facilitated by modern wireless networks, such as $5 \mathrm{G}$ that will support more data capacity than ever before, and connect unlimited numbers of end-user, technologies, and smart software (Li et al., 2017).

\subsubsection{Educators 4.0 and the changing roles of teachers and students}

Educators 4.0 should have the competences that enable them managing highly collaborative learning environments that blind physical and cyber realities, and becomes experts in choosing the appropriate learning resources, and can make best use of learning analytics to monitor and evaluate the performance of learners. In addition, educators 4.0 should be able to employ emerging technologies in teaching and learning, and use innovative teaching strategies such as: maker learning, Open educational resources (OER), flipped learning, gamification, and Open learning with MOOC (Mokhtar, Alshboulland Shahin, 2019). The roles of teachers and students have been changed, as the student became the center, and the teacher's role was limited to guidance and work as a facilitator in an highly collaborative environment supported by artificial intelligence and all the required information is available (Sudibjo, Idawati, Harsanti, 2019).

\subsubsection{Computational thinking and "Digital Intelligence"}

The rapid developments of technology has created new complex technological problems that require innovative solutions that necessitate a mix of critical thinking with computational thinking which was introduced by S. Papert for the first time, then introduced by Wing who described it as a new a way of thinking stemmed from ideas derived from mathematics, engineering, technology and science and used to solve problems, design systems, and understand human behaviors through using principles of computer science (Wing, 2006). Yuhyun Park (2016) introduced the concept of digital intelligence, as a new type of human intelligence, which is based on Gardner's Multiple Intelligence Theory (1983). Park defined digital intelligence as a set of social, emotional, and cognitive capabilities that enable individuals to confront challenges and fulfil the requirements of digital life. These capabilities can be generally divided into eight interrelated areas and 24 competencies as shown in the model developed by The DQ Institute (DQI). The model aims at describing and defining competencies as an educational framework as shown in Table 1. (Krištof, Morić \& Maras, 2018). 


\begin{tabular}{|c|c|c|c|c|c|c|c|c|}
\hline & $\begin{array}{l}\text { Digital } \\
\text { Identity }\end{array}$ & $\begin{array}{l}\text { Digital } \\
\text { Use }\end{array}$ & $\begin{array}{l}\text { Digital } \\
\text { Safety }\end{array}$ & $\begin{array}{l}\text { Digital } \\
\text { Security }\end{array}$ & $\begin{array}{l}\text { Digital } \\
\text { Emotional } \\
\text { Intelligence }\end{array}$ & $\begin{array}{l}\text { Digital } \\
\text { Communication }\end{array}$ & $\begin{array}{l}\text { Digital } \\
\text { Literacy }\end{array}$ & $\begin{array}{l}\text { Digital } \\
\text { Righits }\end{array}$ \\
\hline $\begin{array}{l}\text { Digital } \\
\text { Citizenship }\end{array}$ & $\begin{array}{l}{ }^{1} \\
\text { Digital Citizen } \\
\text { Identity }\end{array}$ & $\begin{array}{l}2 \\
\text { Balanced Use of } \\
\text { Technology }\end{array}$ & $\begin{array}{c}\text { Behavioural } \\
\text { Cyber-Risk } \\
\text { Management }\end{array}$ & $\begin{array}{c}4 \\
\text { Personal Cyber } \\
\text { Security } \\
\text { Management }\end{array}$ & Digital Empathy & $\begin{array}{c}6 \\
\text { Digital Footprint } \\
\text { Management }\end{array}$ & $\begin{array}{l}\text { Media and } \\
\text { Information } \\
\text { Literacy }\end{array}$ & $\begin{array}{c}\text { Privacy } \\
\text { Management }\end{array}$ \\
\hline $\begin{array}{l}\text { Digital } \\
\text { Creativity }\end{array}$ & ${ }^{\text {DigitalCo- }}{ }^{9}$ & $\begin{array}{c}10 \\
\text { Healthy Use of } \\
\text { Technology }\end{array}$ & $\begin{array}{l}\text { Content Cyber- } \\
\text { Risk } \\
\text { Management }\end{array}$ & $\begin{array}{c}\text { Network } \\
\text { Security } \\
\text { Management }\end{array}$ & $\begin{array}{c}13 \\
\text { Self-Awareness } \\
\text { and } \\
\text { Management }\end{array}$ & $\begin{array}{c}\text { Online } \\
\begin{array}{c}\text { Communication } \\
\text { and } \\
\text { Collaboration }\end{array}\end{array}$ & $\begin{array}{c}15 \\
\begin{array}{c}15 \\
\text { Content Creation } \\
\text { and }\end{array} \\
\begin{array}{c}\text { Computational } \\
\text { Literacy }\end{array}\end{array}$ & $\begin{array}{c}16 \\
\text { Intellectual } \\
\text { Property Rights } \\
\text { Management }\end{array}$ \\
\hline $\begin{array}{l}\text { Digital } \\
\text { Competitiveness }\end{array}$ & $\begin{array}{l}\text { Digital } \\
\text { Changemaker } \\
\text { Identity }\end{array}$ & $\begin{array}{l}{ }^{18} \\
\text { Civic Use of } \\
\text { Technology }\end{array}$ & $\begin{array}{l}19 \\
\text { Commercial and } \\
\text { Community } \\
\text { Cyber-Risk } \\
\text { Management }\end{array}$ & $\begin{array}{l}20 \\
\text { Orgarisational } \\
\text { Cyber Security } \\
\text { Management }\end{array}$ & $\begin{array}{l}{ }^{21} \\
\text { Relationship } \\
\text { Management }\end{array}$ & $\begin{array}{l}22 \\
\text { Public and Mass } \\
\text { Communication }\end{array}$ & $\begin{array}{c}\text { Data and Al } \\
\text { Literacy }\end{array}$ & $\begin{array}{l}\text { Participatory } \\
\text { Rights } \\
\text { Management }\end{array}$ \\
\hline
\end{tabular}

Table 1. DQ Competencies, source: htps://www.dqinsttute.org/dq-framework/

The challenge that face universities today is how to integrate digital intelligence into their educational processes (Dostál et al., 2017).

\subsubsection{Interdisciplinary platform university}

The implications of the Fourth Industrial Revolution required the emergence of the interdisciplinary university based on advanced technological architecture. Owing to the convergence of man and smart technologies, the subject distance between humanities, science and technology will be decreased. Essential factors for a successful University-as-a-Platform: 1- award inter-, multi-, and across disciplinary degrees; 2- Mix of providing service methods (e.g., blended learning, MOOCs, etc.); 3- the development of Internet of Things; 4- integrating education activities into the software system of the university; 5- innovative digital infrastructure; 6 - developed connectivity among all parties(Xing, \& Marwala, 2017).

\subsection{Assessing the readiness of Egypt for Industry 4.0 \\ 7.1. Background to Egypt context}

Industry 4.0 is just around the corner in the Egypt economy (MOHESR,2019). This section investigates the level of preparedness of Egypt for Industry 4.0 and society 5.0 implementation. Egyptian government policies and initiatives in this regard are reviewed and presented. Key statistics on higher education, skills and employment are presented and analyzed to assess how well prepared the higher education system to supply skills required in Industry 4.0. and society 5.0. Egypt has now started taking decisions and implementing various initiatives to reform its educational higher education system after 60 years of lack of development and clear changes. The indicators confirm that the Fourth Industrial Revolution will cause a large proportion of those with intermediate skills will lose their jobs. This issue will put Egypt at great risk due to its heavy dependence on routine jobs and intermediate skills. These jobs are expected to be fully automated due to the introduction of artificial intelligence, and studies of futurists, economists and international organizations such as International Labor Organizations (ILO), the World Bank and the World Economic Forum (WEF) have suggested that if middle-skilled people do not try to develop their skills, they will lose their jobs (Samans and Zahidi, 2017).

As for Egypt's adoption of smart technologies that represent the core of Industry 4.0, Egypt is still in the very early stages compared to other countries in, Europe, United States, and Asia (GMIS, 2019). According to Government Artificial Intelligence Readiness report (2019) Egypt ranks 111 out of 194 countries.

\subsection{Developing a future-ready workforce}

According to the World Economic Forum's Competitiveness Report (2019), the level of education quality in Egypt scored below the global average. According to the Central Agency for Public Mobilization and Statistics (CAPMAS), in 2019, the unemployment rate (15-64) is at 7.5\% and the unemployment rate (15-29) is at 6.7\% of the workforce. As maintained by the World Economic Forum, the unemployment rate in Egypt could increase on the grounds that it is estimated that $49 \%$ of work activities in Egypt are liable to automation (Samans and Zahidi, 2017). Egyptian universities graduates are the second largest group of unemployed with $34 \%$, and this percentage indicates that graduates have not been prepared in a way that suits the requirements of industry and the labor market (CAPMAS, 2019).

\subsection{Sustainable development strategy: Egypt 2030}

In 2015, President Abdel Fattah El Sisi launched the Sustainable Development Strategy: Egypt 2030. It aimed to achieve a competitive advantage for Egypt in the global economy through achieving comprehensive and balanced 
economic development. The strategy is based on three main strategic dimensions, and ten pillars underlying these dimensions, which are illustrated in the form (SDS Egypt, 2015).

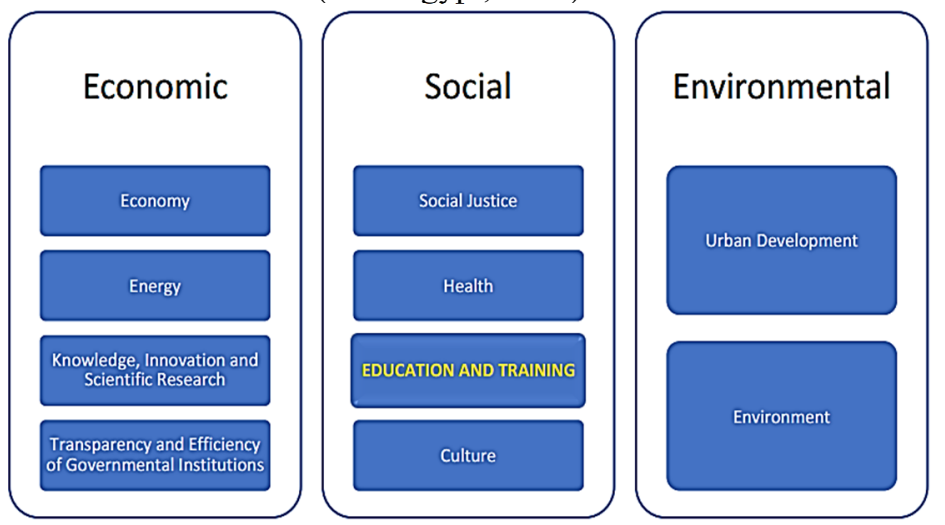

Figure 6: Three main strategic dimensions and the ten pillars of SDS.

Source:(SDS, 2015)

Egypt has taken several steps towards adopting Education 4.0 and the Egyptian Ministry of Higher Education \& Scientific Research has exerted great efforts to adopt education 4.0, some of these efforts are summarized as follows (Information Center, 2018): -

1. There are (27) public Egyptian universities and, there is a trend towards expansion in private universities to reach the number (32 universities by the year 2030), which are oriented towards science and technology. In addition, establishing the Science and Innovation City in the new capital that includes advanced research centers in Science, Technology and Artificial Intelligence sectors.

2. The Ministry Established (22) data centers in public Egyptian universities to increase the speed of the Internet From 34 Mega to $3 \mathrm{G}$ Speed. In addition to, 140 units of electronic services and 17 training centers for building capacities of academic staff in employing information and communication technology in educational process and conducting scientific research.

Haddaraab and Elragal (2015)conducted a study to assess the readiness of Enterprise resource planning (ERP) systems in Egypt as they are the backbone for the Industry 4.0, they concluded that as a result of the repercussions of the January 2011 revolution, Egypt has undertaken comprehensive and deep economic reforms, and it is best for Egypt to increase investment in Enterprise Resource Planning (ERP) systems, which reduces dependence on large numbers of low or medium skilled workers in most of the current industries that therefore require huge labor costs. Thus, automation can reduce high production costs and speed up the production cycle. Utikal, Ebert and Nauruschat (2019) investigated the current status of the Industry and the potential of its sustainability 4.0 in Egypt as an emerging country, they stated the following results as shown in table 2: -

Table 2. the current status of the Industry 4.0 in Egypt

Source: (Utikal, Ebert and Nauruschat, 2019)

\begin{tabular}{|c|c|c|c|}
\hline Egypt & Selected Key Faots & Key Opportunities and Challenge & Implication for $14.0 /$ Sustainability \\
\hline $\begin{array}{l}\text { Technology } \\
\text { \& Innovation } \\
\text { Ranks 53/100 }\end{array}$ & $\begin{array}{l}\text { Technology platform }(42 / 100) \\
\text { with FDI and technology transfer } \\
(61 / 100) \text {; weak technology absorp- } \\
\text { tion on company level }(84 / 100) \\
\text { Ability to innovate }(72 / 100) \text { : venture } \\
\text { capital deal flow }(46 / 100) \text {; R8D ex- } \\
\text { penditure (ranks } 49 / 100 ; \text { Companies } \\
\text { embrace disruptive ideas ( } 95 / 100) \text {; } \\
\text { scientific and technical publication } \\
(57 / 100)\end{array}$ & $\begin{array}{l}\text { Building of manufacturing processes } \\
\text { as a ohallenge; weak position in FDI } \\
\text { and technology transfer and weak } \\
\text { technology absorption capacity } \\
\text { Weak ability to innovate } \\
\text { Companies not embracing disruptive } \\
\text { ideas }\end{array}$ & $\begin{array}{l}\text { Potential for leapfrogging given - } \\
\text { special attention has to be given to } \\
\text { the question how the basio capabil- } \\
\text { ities for generating and disseminat- } \\
\text { ing innovation can be fostered }\end{array}$ \\
\hline $\begin{array}{l}\text { Human Capital } \\
\text { Ranks } 85 / 100\end{array}$ & $\begin{array}{l}\text { Current labor force with weak pro- } \\
\text { file }(78 / 100) \text { : still very high number } \\
\text { of unskilled workers: mean years of } \\
\text { schooling }(82 / 100) \text {, timited digital } \\
\text { skills }(64 / 100) \\
\text { Future labor force in a weak po- } \\
\text { sition }(95 / 100) \text { : Quality of univer- } \\
\text { sities }(45 / 100) \text {; Vocational training } \\
(100 / 100) \text {; th the job training } \\
(100 / 100) \text {, School life expectancy } \\
(71 / 100)\end{array}$ & $\begin{array}{l}\text { Upgrading of skillset as major } \\
\text { challenge } \\
\text { Low level out of school plus severe } \\
\text { challenges in the fields of vocational } \\
\text { and on the job training }\end{array}$ & $\begin{array}{l}\text { Upskilling of workforce needed in } \\
\text { order to have high tech manufactur- } \\
\text { ing processes in Egypt } \\
\text { Developing a vocational training and } \\
\text { on the job training culture as major } \\
\text { challenge } \\
\text { Integrate Industry } 4.0 \text { and sustaina- } \\
\text { bility topios into curriculum for aca- } \\
\text { demic and non-academic trainings } \\
\text { Making sustainability issues mean- } \\
\text { ingful for unskilled workers }\end{array}$ \\
\hline $\begin{array}{l}\text { Global Trade } \\
\& \text { Investment } \\
\text { Ranks } 75 / 100\end{array}$ & $\begin{array}{l}\text { Irade }(96 / 100) \text { : High trade barriers } \\
\text { Investment }(30 / 100) \text { : High greenfield } \\
\text { investments }(9 / 100) \text {; investment } \\
\text { inflow }(37 / 100) \\
\text { Infrastructure }(54 / 100) \text { : electricity } \\
\text { infrastructure }(56 / 100) \text {; transport } \\
\text { infrastructure }(53 / 100)\end{array}$ & $\begin{array}{l}\text { Global trade is not systematical- } \\
\text { ly used as a mean for enhancing } \\
\text { learning on Industry } 4.0 \\
\text { high greenfield investments can be a } \\
\text { mean for knowledge transfer } \\
\text { Infrastructure as a challenge for } \\
\text { Industry } 4.0\end{array}$ & $\begin{array}{l}\text { Global trade and investment as a } \\
\text { relevant field for improving sustain- } \\
\text { able economic development - but } \\
\text { trade barriers as a major barrier } \\
\text { Infrastructure as a field for further } \\
\text { improvement }\end{array}$ \\
\hline $\begin{array}{l}\text { Institutional } \\
\text { framawork } \\
(78 / 100)\end{array}$ & $\begin{array}{l}\text { Future orientation of government } \\
\text { (56/100) } \\
\text { Regulatory efficiency }(74 / 100) \\
\text { Rule of law }(79 / 100) \\
\text { Incidence of corruption }(75 / 100)\end{array}$ & $\begin{array}{l}\text { Uncertainties with regard to the } \\
\text { institutional framework prevent } \\
\text { deployment of Industry } 4.0 \text { tech- } \\
\text { nologies and timit willingness to } \\
\text { experiment with new technologies }\end{array}$ & $\begin{array}{l}\text { Factor has to be taken into account } \\
\text { as a limiting factor for future devel- } \\
\text { opment }\end{array}$ \\
\hline
\end{tabular}




\subsection{S.W.O.T. Analysis}

After describing the current situation of readiness of Egypt for Industry 4.0, it has been necessary to conduct SWOT analysis to identify opportunities, threats, strengths and weaknesses of public Egyptian universities in terms of adopting and adapting to the requirements of the Fourth Industrial Revolution and Society 5.0 to prepare students for the future labor market. The following list reveals the experts' collective agreed upon factors in relation to each category, as stated below.

\subsubsection{Strengths}

1. Faculty are impressed by the potentials of Education 4.0.

2. There is positive willingness of leaders of universities to reinforce inter-college cooperation among faculty and deans to advance Education 4.0.

3. There is recognition that Education 4.0 matters.

\subsubsection{Weaknesses}

1. Difficulty of changing the educational paradigm and fixed mindset of those who responsible for preparing the current and future workforce for the Fourth Industrial Revolution and Society 5.0.

2. There is no unified strategic plan for adapting public Egyptian universities to prepare the current and future workforce for the Fourth Industrial Revolution and Society 5.0.

3. Adapting processes are difficult to manage due to the difference in infrastructures of universities.

4. Scarcity of experienced faculty with the suitable competencies.

5. Difficulty of changing ways of thinking and doing things.

6. There are no standardized regulations for developing interdisciplinary courses.

7. The instructional technologies needed require expensive logistical infrastructure.

8. Infrastructure needed to implement Education 4.0 is highly expensive.

9. There are insufficient financial, technical and technological support systems.

10. There is a digital divide.

11. There is a limited number of smart classrooms.

12. There is a limited-speed and inadequate coverage of internet access and Wi-Fi.

13. There are no big data analytics labs.

14. There are insufficient communication flow systems.

15. There is weak communication with alumni and there is no advanced alumni management system.

16. There are inflexible regulation, administrative bylaws, and procedures that are unsuitable for Education 4.0.

17. Non-strategic location of universities; they are distant from industrial areas.

18. Academics and staff resistance to accept extra tasks and to learn new ways of doing things.

\subsubsection{Opportunities}

1. The political commitment of adopting Education 4.0 and Society 5. 0.

2. Security and political stability.

3. Improving the economic conditions and investment opportunities.

\subsubsection{Threats}

1. Lack of unified strategic future directions towards adopting Education 4.0 and Society 5. 0.

2. Lack of cooperation between industry sector and universities.

3. Lack of community and media recognition and awareness of the importance of STEM skills and careers.

4. Lack of government funding and limited resources.

5. There is no a national governance structure for Education 4.0 and Society 5. 0 .

8.0. A suggested strategic roadmap for public Egyptian universities to adopt and adapt to the requirements of the Fourth Industrial Revolution and Society 5.0 to prepare students for the future labor market There was agreement at the World Economic Forum 2016, that all schools and universities "should not teach the world as it was, but as it will be." (Wisskirchen et al., 2017) Therefore, a strategic roadmap is offered which highlights strategic goals, objects and the actions that should be implemented to ensure that public Egyptian universities will be able to prepare the current and future workforce for the Fourth Industrial Revolution and Society 5.0.

\subsection{Strategic goals}

Public Egyptian universities should focus on seven main strategic goals, they should:

1. develop a new transformative educational paradigm based on Cybergogy and Peeragogy.

2. reengineer university education system.

3. develop fluid and organic curricula responding to transformative innovations \& state of art of knowledge and sciences.

4. adopt appropriate ubiquitous emerging technologies. 
5. develop innovative smart partnerships with stakeholders.

6. prepare capable faculty and staff.

7. adopt research 4.0

To achieve these goals the following strategic objectives should be achieved:

1. Develop a new transformative educational paradigm based on Cybergogy and Peeragogy

1.1 Adopt a concept of education

Universities should reformulate their strategic roadmaps to remain relevant for Education 4.0. First of all, they should redefine the concept of education as:

" the kind of education that is human-centered, oriented towards the new society 5.0 ,sustainable, fluid and driven by values, powered by intellect and managed by new ubiquitous emerging technologies in an highly collaborative environment supported by the integration between human and artificial intelligence, with an emphasis on humanistic perspectives, innovation and progressive thinking, in terms of dynamic ecosystem and positive culture that penetrate every feature of the educational process."

1.2 The new nature of knowledge

Knowledge will not be confined to the classroom, but will extend beyond the classroom, and has many forms, including MOOCs. The sources of knowledge are global and the Internet will become the main place for the flow of knowledge. In addition, the learning process will be based on a two-way exchange of knowledge between the educators and learners.

\section{1-3 Learning theory, orientation and modes}

a) Connectivism as a new learning theory should be adopted.

b) Cybergogy (virtual-based learning) Heutagogy (self-based learning), and peeragogy (peer-oriented learning) become the future mode of teaching and learning.

c) Learning orientation should be student-centered, peer-to-peer, challenge-based, competency-based, personalized and deep learning approach.

d) Enhance and expand workplace learning/work-based learning.

e) Applying emerging smart technologies to develop:

$>$ Adaptive learning.

$>$ Just in time, micro learning.

$>$ Life wide and lifelong learning.

\subsection{Nature of learners}

a) Learners are digital natives, creators of knowledge and self-explorer.

b) learners will be prepared to learn about and through emerging smart technologies.

c) learners should acquire the skills and knowledge that enable them to live in a world where the use of independent and smart computing is widespread in all societal systems.

d) The graduate will not only be an expert in a specific field, but will acquire knowledge, skills and competencies that enable him/ her to join the business environment as a partner or as an owner.

e) Learners should acquire the basic skills necessary for success in online platform markets such as: digital skills, a mix of "entrepreneurial", "self-branding", "communication" and "organizational skills", as well as personal behavior.

\section{Reengineer higher education system}

\subsection{Change educational policies}

This strategic objective can be achieved by:

a) University policies should focus on smart emerging technology as a dynamic drive for change.

b) Universities will not only operate in accordance with the national standards but also, they will adopt the standards set by transnational "digital institutions" and platform companies.

c) University will become committed to the regulations of a "loose institution".

d) University education system must support DQ education.

e) Processing of big data should be among the priorities of university education.

f) Requirements of the fourth industrial revolution and society 5.0 should be aligned with formal higher education policies.

g) The policy of cohort-based classes should be changed.

\subsection{Regulations}

Regulations and laws for recognizing "online" programs using the "Internet" as a learning tool should be developed, with the establishment of rules for quality control, certification and privacy of information.

2.3 Develop personalized dynamic university education system

a) University education system should be supported to become personalized by making education available anywhere and anytime, with great attention to innovation and creativity.

b) Mechanisms to enable university education system to be evolving and dynamic to prepare students for non-linear career paths should be developed. 
c) University should augment traditional degrees with employer-verified badges and certifications.

\subsection{Provide on-demand learning}

University should Provide 'fluid' not limited to university years programs and courses (wherever, whatever, whenever and however the learners want).

\section{2-5 Suitable investment}

University should search for diverse innovative public, private, and international sources and mechanisms of funding.

\subsection{Upgraded management information systems}

Integrating emerging technologies to upgrade education management information systems (EMIS) to enhance data collection and processing for supporting evidence-based reporting on learning and context in order to improve the learning process and environment.

\subsection{Ethical and transparent issues}

Laws and regulations governing open access to data, data ownership, data privacy and data availability for public should be developed.

3. Develop fluid and organic curricula responding to transformative innovations \& state of art of knowledge and sciences

\subsection{Design relevant programs and curricula}

a) Developing curricula that focus on interaction between robot and human systems.

b) Curricula will require new quality and certification standards in terms of the requirements of industry 4.0.

c) Developing new fluid and organic interdisciplinary and across campuses programs and courses to fulfill the Fourth Industrial Revolution requirement.

d) Programs and curricula should be dynamically reviewed and adjusted to promote in-depth integration of emerging technologies and global standpoints.

e) Anticipating and identifying current and future knowledge, skills and competences to ensure the relevance of curricula to the changing requirements of industry 4.0 and society5.0. Figure 7 indicates the competencies that learners need to gain to be an effective participating member of the future society.

f) Identify quality standards and rubrics of the quality of OERs and MOOCs.

g) Facilitating institutional networks and collaboration to effectively use OER and MOOCs.

h) Develop A la Carte and Do it yourself (DIY) courses.

i) Focus on providing learners with unbeatable knowledge, skills and competencies through developing new programs with flexible structures to enable learners to perform lifelong and collaborative learning, provided that these programs provide learners with multiple options to enter, exit and join other programs.

j) Multidisciplinary program should be tailored to fulfill current and future needs of many diverse learners.

k) Apply learning analytics solutions as a tool to develop all curricula.

l) Merge Adaptability Quotient (AQ) in curricula as a necessary element for learners to face the requirements of industry 4.0.

m) Provide learners with the knowledge, skills and competencies of self-employment through the use of business sharing platforms in the era of "Gig economy", as well as the skills and knowledge that will become the most in demand in the labor market during the coming years in various sectors of development.

n) Merge computational thinking, emerging science, technology, engineering, mathematics and programming skills into curricula.

o) Offer personalized user-generated and DIY (Do It Yourself) content.

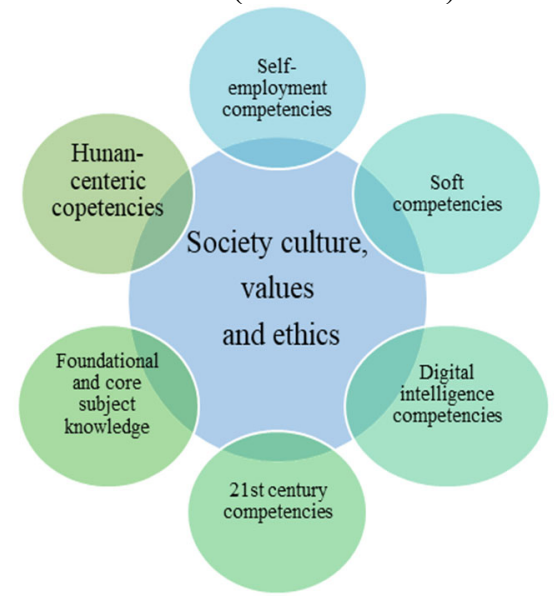

Figure 7: The competencies learners need to gain. 


\section{Adopt appropriate ubiquitous emerging technologies}

a) Develop AI-based platforms and data-based learning analytics as fundamental technologies to offer flexible personalized learning pathways.

b) Provide opportunities vulnerable students and develop tools and mechanism to overcome the digital divide.

c) Build infrastructures that integrate digital and real spaces to support a wide range of educational needs.

d) The educational environment of university education must support challenge-based, passion-based and engaged learning. In addition, it must be fluid, smart, and allow flexible mobility of learners in physical and virtual spaces.

e) Develop learning highly collaborative environment based on virtual and augmented reality technologies that support the independence of the learners while providing collaborative learning opportunities.

f) Adopt educational factories as a very important method for applying technical knowledge and skills.

g) Adopt wearables assisted teaching and learning technologies.

\section{Develop innovative smart partnerships}

a) Universities should adopt "quadruple helix model of innovation "as a new mode of partnership.

b) Universities should Expand capstone projects supported by community and industry.

c) Universities should develop partnerships with social media platforms for enhancing Cybergogy and Peeragogy.

d) Universities should develop platforms for enhancing partnerships with alumni who could facilitate industry-academia linkages nationally and internationally.

e) Universities should develop partnerships with world-class universities.

f) Universities should develop more industry student engagement partnerships.

\section{Prepare capable faculty and staff}

\subsection{Educators 4.0}

This strategic objective can be achieved by: -

a) Purposefully reviewing academics' roles and prerequisite competencies in the context of university education policies to develop relevant and capacity-building programs to prepare academics to efficiently and effectively manage emerging technologies-rich education settings.

b) Developing professional development programs for academic and administrative staff to acquaint them with Education 4.0 competencies.

c) Developing professional development programs to enable academics to efficiently and effectively use learning analytics to develop and update curriculum, monitor and assess the performance of the learners.

d) Developing academic staff skills to effectively use the Internet of Things to analyze and explore student cognitive patterns, and design better learning outcomes.

e) Developing academic staff skills to effectively use innovative teaching strategies such as: maker learning, Open educational resources (OER), flipped learning, gamification, and Open learning with MOOC.

f) Developing academic staff skills to effectively use the Internet of Things to form research groups from various countries of the world for research cooperation in groups with common research interests and directions.

\section{Adopting research 4.0}

a) A strategic plan for enhancing Research 4.0 that is based on university-industry collaboration to support conducting applied research with real-world impact should be developed.

b) A digital innovation hub should be established.

\subsection{Essential enablers and requirements for implementing strategic roadmap:}

Implementation of the proposed strategic roadmap requires the following enablers and requirements:

a) Raising awareness and understanding of the necessity of Education 4.0. among all internal and external stakeholders of university Education.

b) Developing policies and models for supporting and guiding implementation.

c) Establishing a system of experts to provide instant feedback, as well as technical and technological support systems.

d) Providing funding for applying the necessary changes which should be managed by transformational leaders to maintain their sustainability.

e) Establishing cooperation and partnership agreements with (industry, civil society, national and global Universities, alumni... etc.) in terms of quadruple helix approach to support implementing change processes.

f) Establishing a center for producing educational resources using new emerging technologies including augmented reality (AR) / virtual reality (VR), mixed reality (MR), robotics, and big data analysis, AI, IoT, Blockchain, and Gamification to create innovative learning experiences.

g) Creating a cloud-based platform for enhancing educational experiences and on-demand services. 
h) Developing the suitable infrastructure and wireless connectivity to enable (100\%) smart classrooms to be actively used and maker spaces to be available on all campuses.

i) Establishing Wide-range platforms for developing Education 4.0.

j) Implanting culture of innovation and making to be as second nature to learners and academic staff.

k) Breaking down the walls between universities and community.

\subsection{Concluding remarks and outlook}

I believe that manifestations of the Fourth Industrial Revolution represent only the top of the iceberg. It has started with the emergence of Cyber-Physical Systems (CPS) that are controlled by computer programs via the internet, and these systems have a capacity for continuous improvement in a striking way. The big question that arises here is: Will the Fourth Industrial Revolution and society 5.0 contribute to creating a more just, inclusive and sustainable society, or will it increase the social divide and polarization of ideas?

The paths of the future depend on what is taking place at the present time; hence future transformations in various sectors and industries should be foreseen if university education want to contribute to making the future. Given the accelerating emergence of the repercussions of the Fourth Industrial Revolution and society 5.0, those who will know how to anticipate the following major changes will be the ones who will be able to guide the future, and the rest will follow.

\subsection{Recommendations for Further Research}

The rapid labor market changes that characterize the Fourth Industrial Revolution (IR4) and Society 5.0 might highlight the need for additional competencies and knowledge. To ensure relevancy, it is suggested that the identified requirements of the Fourth Industrial Revolution (IR4) and Society 5.0. be explored periodically against the new competencies demands and updated academic works for strategic roadmap updates.

Future research could make a contribution and possibly be generalized to other universities in similar contexts.

\section{References}

Alhefeiti, F. S. O.(2018) Society 5.0:A human-centered society that balances economic advancement with the resolution of social problems by a system that highly integrates cyberspace and physical space. MSc in Informatics Knowledge \& Data Management. The British University in Dubai.

Gladden, M. E. (2019) Who Will Be the Members of Society 5.0? Towards an Anthropology of Technologically Posthumanized Future Societies. Social Sciences 8(5), 1-39.

Anton, P.S., Silberglith, R. Schveeder, J.(2015) The Global Technology Revolution - Bio/Nano/Materials Trends and their Synergies with Information Technology, RAND, Arligngton, VA.

Badmington, N. (2006) Cultural Studies and the Posthumanities. In New Cultural Studies: Adventures in Theory. Edited by Gary Hall and Claire Birchall. Edinburgh: Edinburgh University Press, pp. 260-72.

Bahl, M., Cook, M., and Nerurkar, K. (2018, November) Relearning how we learn, from the campus to the workplace. Center for the Future of Work, Cognizant.

Baldwin, R. (2019) The Globotics Upheaval: Globalization, Robotics, and the Future of Work. New York, NY, Oxford University Press.

Barnes, S.A., Green, A. \& Hoyos, M. (2015) Crowdsourcing and work: individual factors and circumstances influencing employability. New Technology, Work and Employment 30(1), 16-31.

Berg, J, Furrer, M, Harmon, E, et al. (2018) Digital Labour Platforms and the Future of Work: Towards Decent Work in the Online World. Geneva: International Labour Office.

Block, B.-M.,( 2018) Digitalization in engineering education research and practice, IEEE Global Engineering Education Conference (EDUCON), pp. 1024-1028, Santa Cruz de Tenerife, Canary Islands, Spain, April 2018

Bryndin, E. (2018)System Synergetic Formation of Society 5.0 for Development of Vital Spaces on Basis of Ecological Economic and Social Programs. Annals of Ecology and Environmental Science 2(5), 12-19.

CAPMAS(2019). Egypt in Figures:2019

Charles, N., and Davies, C. A. (2011). My Family and Other Animals: Pets as Kin. In Human and Other Animals. London: Palgrave Macmillan, pp. 69-92.

Coccoli, M., Maresca, P., Stanganelli, L. (2016). Cognitive computing in education. Journal of e-Learning and Knowledge Society 12(2), 55-69.

Cohen, S. P.(2002). Can Pets Function as Family Members? Western Journal of Nursing Research 24(6), 621-38.

Conati, C., and Kardan, S. (2013)Student Modeling: Supporting Personalized Instruction, from Problem Solving to Exploratory, Open-Ended Activities. AI Magazine 34(3), 13-26.

Daugherty, P. R., \& Wilson, H. J. (2018) Human+Machine: Reimagining Work in the Age of AI. Boston, MA. Harvard Business Press.

De Stefano, V (2016) The Rise of the "Just-In-Time Workforce”: On-Demand Work, Crowdwork and Labour 
Protection in the "Gig-Economy”. Geneva: International Labour Office.

Deloitte (2014) Agiletown: The Relentless March of Technology and London's Response. London: Deloitte . Available online: https:/www2.deloitte.com/uk/en/pages/growth/articles/agiletown-the-relentless-march-oftechnology-and-londons-response.html\#((accessed on 25 March 2018).

Deloitte (2018) Preparing tomorrow's workforce for the Fourth Industrial Revolution For business: A framework for action. Available online: https:/www2.deloitte.com/content/dam/Deloitte/global/Documents/AboutDeloitte/gx-preparing-tomorrow-workforce-for-4IR.pdf (accessed on 21 June 2919)

Demartini, C., \& Benussi, L. (2017). Do Web 4.0 and Industry 4.0 Imply Education X. 0?. IT Professional, 19(3), 4-7.

Demir, K. A., and Cicibaş, H. (2018) The Next Industrial Revolution: Industry 5.0 and Discussions on Industry 4.0. Industry 4.0 From the Management Information Systems Perspectives. Peter Lang Publishing House.

Demira, K.A. , Dövena, G., Sezen, B.(2019) Industry 5.0 and Human-Robot Co-working. The 3rd World Conference on Technology, Innovation and Entrepreneurship . Procedia Computer Science 158 (2019) 688695.10.1016/j.procs.2019.09.104

Dostál, J., Wang, X., Steingartner, W., Nuangchalerm, P. (2017) Digital intelligence- new concept in context of future of school education. In: proceedings of ICERI2017 Conference.16th-18th November 2017, Seville, Spain, pp. 3706-3712.

Edwards, C. Edwards, A., Spence, P. R., \& Lin, X. (2018) I, teacher: Using artificial intelligence (AI) and social robots in communication and instruction. Communication Education 67(4), 473-480.

Elvis, M., and Milligan, T. (2019) How much of the solar system should we leave as wilderness?" Acta Astronautica, Available online https://doi.org/10.1016/j.actaastro.2019.03.014(accessed on 23 March 2019).

EU-OSHA(2015) A Review of the Future of Work: Online Labour Exchanges or 'Crowdsourcing:Implications for Occupational Safety and Health. discussion paper. European Agency for Safety and Health at Work.

European Commission (2012) Innovating for Sustainable Growth - A Bioeconomy for Europe." Available online: https://ec.europa.eu/research/bioeconomy/pdf/official-strategy_en.pdf(accessed on March 25 2019)

Ferrando, F. (2013) Posthumanism, Transhumanism, Antihumanism, Metahumanism, and New Materialisms: Differences and Relations. Existenz: An International Journal in Philosophy, Religion, Politics, and the Arts. $8(2), 26-32$.

Ferreira, C. M., and Serpa, S. (2018) Society 5.0 and Social Development: Contributions to a Discussion. Management and Organizational Studies 5(4), 26-31.

Gasevic, D. , Wolff, A. , Rose, C. , Zdrahal, Z., Siemens, G. (2014) Learning analytics and machine learning. In: Proceedings of the ACM International Conference Series, pp. 287-288.

Gašević, D., Dawson, S., Siemens, G. (2015) Let's not forget: Learning analytics are about learning, TechTrends. 59(1), 64-71.

Gill, H. (2008) From Vision to Reality: Cyber-Physical Systems. In HCSS National Workshop on New Research Directions for High Confidence Transportation CPS: Automotive, Aviation, and Rail. Available online: http://www2.ee.washington.edu/research/nsl/aar-cps/Gill_HCSS_Transportation_Cyber-Physical_ Systems_2008.pdf (accessed on 19 March 2017).

Gladden, M. E.(2019) Who Will Be the Members of Society 5.0? Towards an anthropology of technologically posthumanized future societies. Socai Science, (5), 148,1-39.

Gleason, N.W. (2018) Higher education in the era of the fourth industrial revolution. Singapore, Palgrave Macmillan.

Global Manufacturing \& Industrialisation Summit (GMIS)(2019) The Future of Manufacturing - Egypt.21 March 2019, The American University in Cairo. Available on line :https://www.google.com/search?client=firefox$\mathrm{b}-\mathrm{d} \& \mathrm{q}=\% 22+$ The + Future + of + Manufacturing $+\% \mathrm{E} 2 \% 80 \% 93+$ Egypt $\% 22++\% 2 \mathrm{C}+$ pdf $\&$ channel $=$ trow2

(accessed on 17 June 2019)

Government of Japan(2016a) The 5th Science and Technology Basic Plan. Provisional translation. January 22. Available online: https://www8.cao.go.jp/cstp/english/basic/5thbasicplan.pdf (accessed on 25 March 2018).

Graham, E. (2002) Representations of the Post/Human: Monsters, Aliens and Others in Popular Culture. Manchester, Manchester University Press.

Graham, E. (2004) Post/Human Conditions. Theology \& Sexuality. 10(2), 10-32.

Granrath, L. (2017) Japan's Society 5.0: Going Beyond Industry 4.0, Available Online < https://www.japanindustrynews.com/2017/08/japans-society-5-0-going-beyondindustry-4-0/> ( accessed on 25 September 2018).

Gulson, K. N., Murphie, A., Taylor, S., \& Sellar, S. (2018) Education, work and Australian society in an AI world. A review of research literature and policy recommendations. (Research Report). Sydney: Gonski Institute for Education, UNSW

Gunkel, D. J. (2012) The Machine Question: Critical Perspectives on AI, Robots, and Ethics. Cambridge: The MIT Press. 
Halili, S. H.(2019) Technological Advancements In Education 4.0. The Online Journal of Distance Education and e-Learning.7(1),63-69.

Haraway, D. (1991) Simians, Cyborgs, and Women: The Reinvention of Nature. New York, Routledge.

Haraway, D. (2003) The Companion Species Manifesto: Dogs, People, and Significant Otherness. Chicago: Prickly Paradigm Press.

Harayama, Y. (2017)Society 5.0: Aiming for a New Human-Centered Society. Japan's Science and Technology Policies for Addressing Global Social Challenges. Interviewed by Mayumi Fukuyama. Hitachi Review. 66: $8-13$.

Hassan, I. (1977)Prometheus as Performer: Toward a Posthumanist Culture? A University Masque in Five Scenes. The Georgia Review. 31(4), 830-50.

Hayles, N. K. (1999) How We Became Posthuman: Virtual Bodies in Cybernetics, Literature, and Informatics. Chicago: University of Chicago Press.

Hayles, N. K. (2005) My Mother Was a Computer: Digital Subjects and Literary Texts. Chicago: University of Chicago Press.

Hazarika, S.(2019) Gig Economy: How it has revolutionized the meaning of work. Master Thesis. Delhi School of Management. Delhi Technological University.

Heinemann, C., \& Uskov, V. L. (2018) Smart university: Literature review and creative analysis. In V. L. Uskov, J. P. Bakken, R. J. Howlett, \& L. C. Jain (Eds.), Smart Universities. Concepts, Systems, and Technologies (pp. 11-46). New York, NY, Springer.

Herbrechter, S. (2012) A Passion so Strange, Outrageous, and So Variable : The Invention of the Inhuman in the Merchant of Venice. In Posthumanist Shakespeares. Edited by Stefan Herbrechter and Ivan Callus. London: Palgrave Macmillan, pp. 41-57.

Herbrechter, S. (2013)Posthumanism: A Critical Analysis. London, Bloomsbury.

Hermann,M., Pentek, T., Otto, B.(2015) Design Principles for Industrie 4.0 Scenarios: A Literature Review. Working Paper No. 01. 2015. Available online: http://www.snom.mb.tudortmund.de/cms/de/forschung/Arbeitsberichte/Design-Principles-for-Industrie-4_0-Scenarios.pdf (accessed on 25 March 2019).

Huws, U. (2014). Labor in the Global Digital Economy. New York: Monthly Review Press.

Hwang, G-J. (2014) Definition, framework and research issues of smart learning environments - a context-aware ubiquitous learning perspective. Smart Learning Environments, 1(4) 1-14.

Information Center (2018) Ministry of Education Higher and Scientific Research. http://portal.mohesr.gov.eg/enus/Pages/default.aspx

Kim, Y., \& Baylor, A. M. (2016) Research-based design of pedagogical agent roles: A review, progress, and recommendations. International Journal of Artificial Intelligence in Education, 26(1), 160-169.

King, J.; Sabelli, N.; and Kelly, H. (2009) Preamble on Policy Issues. Paper presented at the Global Resources for Online Education (GROE), Tempe Arizona, 23-26 April.

Kitsuregawa, M.(2018) Transformational Role of Big Data in Society 5.0. Paper present at 2018 IEEE International Conference on Big Data (Big Data), Seattle, WA, USA, December 10-13; Edited by Naoki Abe, Huan Liu, Calton Pu, Xiaohua Hu, Nesreen Ahmed, Mu Qiao, Yang Song, Donald Kossmann, Bing Liu, Kisung Lee and et al. New York: IEEE.

Krištof, T., Morić, Z. \& Maras, L. (2018). Human Digital Index. International Journal of Digital Technology and Economy, 3 (2), 95-122.

Kuek, Siou Chew, et al. (2015) The global opportunity in online outsourcing. Washington, DC, World Bank.

Lange, D. (2018) Unity Blog: Unity and DeepMind partner to advance AI research, Available online: https://blogs.unity3d.com/2018/09/26/unity-and-deepmindpartner-to-advance-airesearch/? ga=2.251087939.490036111.1544416212-586399343.1544416212(accessed on 21 December 2018).

Lehdonvirta, V., et al. (2018) The global platform economy: a new offshoring institution enabling emergingeconomy microproviders. Journal of Management. Available online: https://doi.org/10.1177\%2F0149206318786781(accessed on 27 December 2019).

Lehdonvirta, V., Margaryan, A. and Davies, H.U.W. (2019) Skills formation and skills matching in online platform work: policies and practices for promoting crowdworkers' continuous learning (CrowdLearn). In: CrowdLearnCrowdLearn. European Centre for the Development of Vocational Training. Available online: https://www.cedefop.europa.eu/files/crowdlearn_literature_review.pdf(accessed on 27 December 2019).

Li, X., Li, D., Wan, J., Vasilakos, A. V., Lai, C. F., \& Wang, S. (2017) A review of industrial wireless networks in the context of industry 4.0. Wireless networks, 23(1), 23-41.

Liu D., Huang R., Wosinski M. (2017) Contexts of Smart Learning Environments. In: Smart Learning in Smart Cities. Lecture Notes in Educational Technology. Springer, Singapore.

Liu, J. \& Wang, L.( 2010) Computational Thinking in Discrete Mathematics, IEEE 2nd International Workshop 
on Education Technology and Computer Science, 413-416.

Liu, Z,( 2011) Cyber-Physical-Social Systems for Command and Control. IEEE Intelligent Systems 26(4),92 - 96.

Lorenz, M. et al., (2015) Man and Machine In Industry 4.0 - How will technology transform the Industrial Workforce Through 2025? Boston Consulting Group.

Lovett, M. , Meyer, O. Thille, C. (2008) The open learning initiative: Measuring the effectiveness of the OLI statistics course in accelerating student learning. Journal of Interactive Media in Education. Available online: https://jime.open.ac.uk/2008/14(accessed on 27 May 2018).

Luckin, R., Holmes, W., Griffiths, M., \& Forcier, L. B. (2016) Intelligence unleashed: An argument for AI in education. London, Pearson.

Maini, V. \& Sabri, S. (2017) Machine learning for humans. Available online:https://everythingcomputerscience.com/books/Machine\%20Learning\%20for\%20Humans.pdf(access ed on 2 May 2018).

Manyika, J., Lund, S., Robinson, K., Valentino, J., and Dobbs, R. (2015) A labour market that works: Connecting talent with opportunity in the digital age. McKinsey Global Institute. Available online: http://www.mckinsey.com/global-themes/employment-and-growth/connecting-talent-with-opportunity-inthe-digital-age(accessed on 27 May 2018).

Maria, M., Shahbodin, F., Pee, N.C. (2016) Malaysian higher education system towards industry 4.0 - current trends overview. AIP Conference Proceedings of the 3rd International Conference on Applied Science and Technology.

Martin, D. et al. (2016) Turking in a global labour market. Computer-Supported Cooperative Work. 25(1), pp. 3977.

Medina-Borja, A.( 2017) Smart Human-Centered Service Systems of the Future. In Future Services \& Societal Systems in Society 5.0. Edited by Kazuo Iwano, Yasunori Kimura, Yosuke Takashima, Satoru Bannai and Naohumi Yamada. Tokyo: Center for Research and Development Strategy, Japan Science and Technology Agency, pp. 235-39.

Miah, A. (2008)A Critical History of Posthumanism. In Medical Enhancement and Posthumanity. Edited by Bert Gordijn and Ruth Chadwick. Dordrecht, Springer Netherlands, pp. 71-94.

Ministry of Higher Education and Scientific Research (MOHESR) (2019) Ministry of Higher Education and Scientific Research Strategy 4.0 :"Scientific Research \& innovation and Sustainable Development Goals". Available online: https://www.uneca.org/sites/default/files/uploadeddocuments/ARFSD/2019/ministry_of_higher_education_and_scientific_research_strategy_4.0_scientific_re search innovation_and sustainable_development goals.pdf(accessed on 27 December 2019)

Mokhtar, S. Alshboul1, J. A. Q. and Shahin, G. O. A. (2019) Towards Data-driven Education with Learning Analytics for Educator 4.0. International Conference Computer Science and Engineering. Journal of Physics: Conference Series, IOP Publishing.

Mourtzis, D., Vlachou, E., Dimitrakopoulos, G., \& Zogopoulos, V. (2018) Cyber- Physical Systems and Education 4.0 -The Teaching Factory 4.0 Concept. In Procedia Manufacturing (Vol. 23, pp. 129-134). Elsevier B.V. https://doi.org/10.1016/j.promfg.2018.04.005

Salgues, B. (2018) Society 5.0 Industry of the Future, Technologies, Methods and Tools. London, ISTE Ltd.

Moutaz, H.; Ahmed, E. (2015) The Readiness of ERP Systems for the Factory of the Future. Procedia Comput. Sci. 2015, 64, 721-728

Mustafa Kamal, N. N., Adnan, A. H. M., Yusof, A. A., Ahmad, M. K., \& Mohd Kamal, M. A. (2019) Immersive Interactive Educational Experiences - adopting Education 5.0, Industry 4.0 learning technologies for M'sian universities. In MNNF Network (ed.), Proceedings of the International Invention, Innovative \& Creative (InIIC) Conference, Series 1/2019 (pp. 190-196). Senawang, NS: MNNF Network.

Nisha, J. R.(2018) Evolution of Education: Towards Sensory Emotive Web. International Journal of Science, Engineering and Management (IJSEM) ,3(4), 655-658.

Park, Y. (2016) 8 digital life skills all children need - and a plan for teaching them. World Economic Forum. Available online: hhttps://www.weforum.org/agenda/2016/09/8-digital-life-skills-all-children-need-and-aplan-for-teaching-them/ (accessed on May 11201 )

Pellegrino, J., and Hilton, M., eds. (2012) Committee on Defining Deeper Learning and Twenty-First Century Skills; National Research Council. Atlanta, GA: National Academies Press.

Pesole, A., Urzi Brancati, C., Fernández Macías, E., Biagi, F., \& González Vázquez, I. (2018) Platform workers in Europe evidence from the COLLEEM survey. Luxembourg: Publications Office of the European Commission.

Porayska-Pomsta, K. (2016) AI as a methodology for supporting educational praxis and teacher metacognition. International Journal of Artificial Intelligence in Education, 24(4), 470-497.

Rifkin, J.(2014) The Zero Marginal Cost Society: The Internet of Things, the Collaborative Commons and the Eclipse of Capitalism, St. Martin's Press, NY. 
Rifkin, J.,(2011) The Third Industrial Revolution: How Lateral Power is Transforming Energy, the Economy and the World, Palgrave McMillan, NY.

Rojko, A. (2017). Industry 4.0 Concept: Background and Overview. International Journal of Interactive Mobile Technologies (iJIM), 11(5), 77-14.

Samans, R., Zahidi, S., (2017) The Future of Jobs and Skills in the Middle East and North Africa: Preparing the Region for the Fourth Industrial Revolution. Geneva: World Economic Forum.

Sandberg, A. (2014) Ethics of Brain Emulations. Journal of Experimental \& Theoretical Artificial Intelligence,26(3), 439-57.

Schmidt, F. (2017) Digital labour markets in the platform economy: mapping the political challenges of crowd work and gig work. Friedrich-Ebert Foundation, Germany. Available online: http://library.fes.de/pdffiles/wiso/13164.pdf (accessed on 21 December 2019).

Schwab, K(2016) The Fourth Industrial Revolution, Crown Publishing Goup, N.Y.

Schwab, K. (2018) Globalization 4.0 - what does it mean? World Economic Forum. Available online:https://www.weforum.org/agenda/2018/11/globalization-4-what-does-it-mean-howit-will-benefiteveryone/.(accessed on 21 December 2019).

Schwartz ,J. et al. (2016) The gig economy: Distraction or disruption? Deloitte University Press, Available Available online https://dupress.deloitte.com/dup-us-en/focus/human-capital-trends/2016/gigeconomyfreelance-workforce.html. (accessed on 21 December 2019).

SDS Egypt. (2015) Sustainable Development Strategy: Egypt's vision 2030. Available online: http://sdsegypt2030.com/?lang=en. (accessed on 21 December 2019).

Shiroishi, Y., Uchiyama, K. and Suzuki, N., (2018) Society 5.0: For Human Security and Well-Being. Computer, 51(7), pp.91-95.

Skobelev P. O. and Borovik S. Y. (2017) On the way from Industry 4.0 to Industry 5.0: from digital manufacturing to digital society. International Scientific Journal, Industry 4.0, 2(6), 307-311.

Spohrer, J.(2016) Cognition as a Service: An Industry Perspective. In Future Services \& Societal Systems in Society 5.0. Edited by Kazuo Iwano, Yasunori Kimura, Yosuke Takashima, Satoru Bannai, and Naohumi Yamada. Tokyo: Center for Research and Development Strategy, Japan Science and Technology Agency, pp. $28-43$.

Sudibjo N., Idawati, L., Harsanti, HG R.(2019) Characteristics of Learning in the Era of Industry 4.0 and Society 5.0. Advances in Social Science, Education and Humanities Research, volume 372. International Conference on Education Technology (ICoET 2019).

Suthers, D. D. (2003) Representational Guidance for Collaborative Inquiry. In Arguing to Learn: Confronting Cognitions in Computer-Supported Collaborative Learning Environments, ed. J. Andriessen, M. J. Baker, and D. D. Suthers, 27-46. Dordrecht, The Netherlands: Kluwer Academic.

Timms, M. J. (2016) Letting artificial intelligence in education out of the box: Educational cobots and smart classrooms. International Journal of Artificial Intelligence in Education, 26(2), 701-712.

Tsekeris, C. (2019) Surviving and thriving in the Fourth Industrial Revolution: Digital skills for education and society. Homo Virtualis, 2(1), 34-42.

UNESCO(2019). Report of the International Conference on Artificial Intelligence and Education. Paris: UNESCO.

Utikal, H. Ebert, B., Nauruschat, M. (2019) Industry 4.0 in Sustainable Industrial Areas in Emerging and Developing Countries: Applicability of Technologies and the Role of the Park Management. Deutsche Gesellschaft für ,Internationale Zusammenarbeit (GIZ) GmbH.

Voskoglou, M. Gr. \& Buckley, S.(2012) Problem Solving and Computers in a Learning Environment, Egyptian Computer Science Journal, 36 (4), 28-4.

Voskoglou, M. Gr. (2016) Problem solving in the forthcoming era of the third industrial revolution, International Journal of Psychological Research, 10(4), 361-380.

Voskoglou, M. Gr.(2019) Artificial Intelligence as a Tool in the Modern Education. International Journal of Applications of Fuzzy Sets and Artificial Intelligence (ISSN 2241-1240), Vol. 9 (2019), 125-138

Wadhwa, V. (2016) 6 Big Ways Tech Is Rewriting Society's Rules. Available online:https://singularityhub.com/2016/11/16/6-big-ways-tech-is-rewriting-societys-rules/.(accessed on May 42 2019).

Wallach, W., and Allen. C.(2008) Moral Machines: Teaching Robots Right from Wrong. Oxford, Oxford University Press.

Wang, X., Li, L., Yuan, Y., Ye, P., Fei-Yue, W.( 2016) ACP-based social computing and parallel intelligence: Societies 5.0 and beyond. CAAI Trans. Intell. Technol. 1(4), 377-393.

Wang, Y., Vuran, M. C., and Goddard, S. (2008) Cyber-Physical Systems in Industrial Process Control. $A C M$ Sigbed Review. 5(1).

Watanabe, F., Mori, Y., Kogo, C. (2015) Analyzing learners'subjective evaluation of peer assessment in japan 
massive open online courses. WASEDA Journal of Human Sciences, 28(2) 237-245.

Schütte, G. (2017) What kind of innovation policy does the bioeconomy need?" New Biotechnology, 40 (A), $82-$ 86.

Wing, J. M. (2006) Computational thinking. Communications of the ACM, 49(3), 33-35.

Wisskirchen, G.; Thibault, B.; Bormann, B.U.; Muntz, A.; Niehaus, G.; Soler, G.J.; Von Brauchitsch, B.( 2017). Artificial Intelligence and Robotics and Their Impact on the Workplace. IBA Global Employment Institute: London, UK.

Woolf, B.P. et al.( 2014) AI Grand Challenges for Education. AI Magazine. 34(4), 66-84.

Woolf, B. P. (2009)Building Intelligent Interactive Tutors: Student-Centered Strategies for Revolutionizing ELearning. San Francisco: Morgan Kaufmann Publishers.

World Economic Forum (2017) Realizing Human Potential in the Fourth Industrial Revolution: An Agenda for Leaders to Shape the Future of Education, Gender and Work. White Paper. Geneva: World Economic Forum.

World Economic Forum (2019) Global Competitiveness Report 2018-2019. Geneva: World Economic Forum. Available online: http://www3.weforum.org/docs/WEF EGW Whitepaper.pdf.(accessed on May 4 2019)

Xing, B., \& Marwala, T. (2017) Implications of the Fourth Industrial Age on Higher Education. Available online: http://arxiv.org/abs/1703.09643. (accessed on August 2 2019)

Xu, M., David, Kim, M. J. \& Kim, S. H. (2018) The Fourth Industrial Revolution: Opportunities and Challenges. International Journal of Financial Research, 9(2), 90-95.

Yasuura, H. (2017) ICT Impact to Society and Education. In Future Services \& Societal Systems in Society 5.0. Edited by Kazuo Iwano, Yasunori Kimura, Yosuke Takashima, Satoru Bannai and Naohumi Yamada. Tokyo: Center for Research and Development Strategy, Japan Science and Technology Agency, pp. 220-222. 